\title{
"Der var et allerhelvedes Fremad i hendes Færd" Georg Brandes møder Vinnie Ream, amerikansk billedhuggerinde
}

af fhv. forskningsbibliotekar Merete Licht

\author{
"Here comes my sister... she's an American girl" \\ Henry James: Daisy Miller
}

"Jeg havde ei troet at jeg skulde komme til Rom for at lagges $i$ amerikanske Rosenlanker! Georg Brandes: Brev til Forældrene,

19. October, 1870

Dette er i ikke et bidrag til det - selv i vor tid - tilsyneladende så uudtømmelige emne: Brandes og kvinderne - snarere tværtimod. Emnet er: Brandes og forståelse. I dette tilfælde forståelse af en kvindetype, han ikke havde været ude for før og derfor ikke havde forudsætninger for at forstå. En kvindetype, som den amerikanske forfatter Henry James brugte et helt forfatterliv på at forklare europæerne. Pointen er, at Brandes umiddelbart - eller rettere i løbet af 17 dage - forstod alt det, James i sit forfatterskab har forsøgt at forklare europæerne om emnet.

I sidste halvdel af det 19. århundrede dukkede et nyt fænomen op på den europæiske arena, nemlig "the American girl". Dette var ikke, som man let kunne forledes til at tro, blot en ung pige fra Amerika. Heller ikke var det den rige arving fra det nye self-made demokrati, der kom til Europa, giftede sig med en mere eller mindre falleret aristokrat og reddede familiegodset, i lighed med f.eks. Jennie Jerome, Winston Churchills moder. Det var en helt ny kvindetype, et væsen der vendte op og ned på europæiske begreber om kvindeliv og kvindemoral og ikke blot en bizar 
amerikansk afvigelse fra normen, d.v.s. den europæiske norm for unge piger og deres optræden.

På begge sider af Atlanten var ægteskabet skæringspunktet mellem to slags kvindeliv i sidste århundrede, og det er deres indplacering i de to kulturer, der giver os nøglen til forståelsen - og dermed også til misforståelsen - af den unge amerikanske pige. Deres indplacering er nemlig spejlvendt, hvorfor man oplever det besynderlige fænomen, at stort set den samme moralkodex i det 19. århundrede finder sin diametralt modsatte tolkning på hver sin side af Atlanten. Dette var baggrunden for, at "the American girl" undertiden forekom europæere som et væsen fra en anden klode. Hvor hun var fri, var hendes europæiske søster bundet af sociale konventioner, og inden for de sociale rammer, hvor den europæiske pige færdedes hjemmevant, havde den amerikanske unge pige ingen fornemmelse for sociale skel endsige for farerne forbundet med at overtræde dem. Dette på eengang frigjorte og uvidende væsen dukkede op i de europæiske dagligstuer og saloner i anden halvdel af århundredet.

Hun havde en efter europæiske begreber uhørt frihed før ægteskabet - hun kunne f..eks. som i Vinnie Reams tilfælde være familiens overhoved og dermed både beskytter og forsørger af sine forældre - på den anden side havde hun en ligeså uhørt bundethed efter ægteskabet. Fra det øjeblik hun giftede sig blev "the American girl” automatisk forvandlet til "the American matron", for i Amerika drejedes nøglen ud til friheden om med ægteskabet, hvor hun blev spærret inde af sociale og - især - af moralske konventioner. Modsat den europæiske pige, der var ufri og strengt overvåget før giftermålet, men var relativt fri inden for ægteskabets beskyttende sociale ramme. Henry James har i sit forfatterskab skildret misforståelserne på begge sider af Atlanten, Amerikanernes mistolkning af det europæiske ægteskab i romanerne The Ambassadors og The Golden Bowl, mens europæernes mistolkning af den amerikanske unge piges færden og udstrakte frihed har fået sit mest prægnante udtryk i novellen Daisy Miller, hvis navn er blevet identisk med "the American girl”.

\section{Rom 1870: The American girl}

Det var Daisy Miller Georg Brandes helt uforberedt mødte, da han i toget til Rom blev tiltalt af Vinnie Ream. Det usædvanlige var, at han - alle Don Juan klicheerne til trods - næsten fra første færd aflæste hende korrekt, modsat f.eks. Winterbourne, 


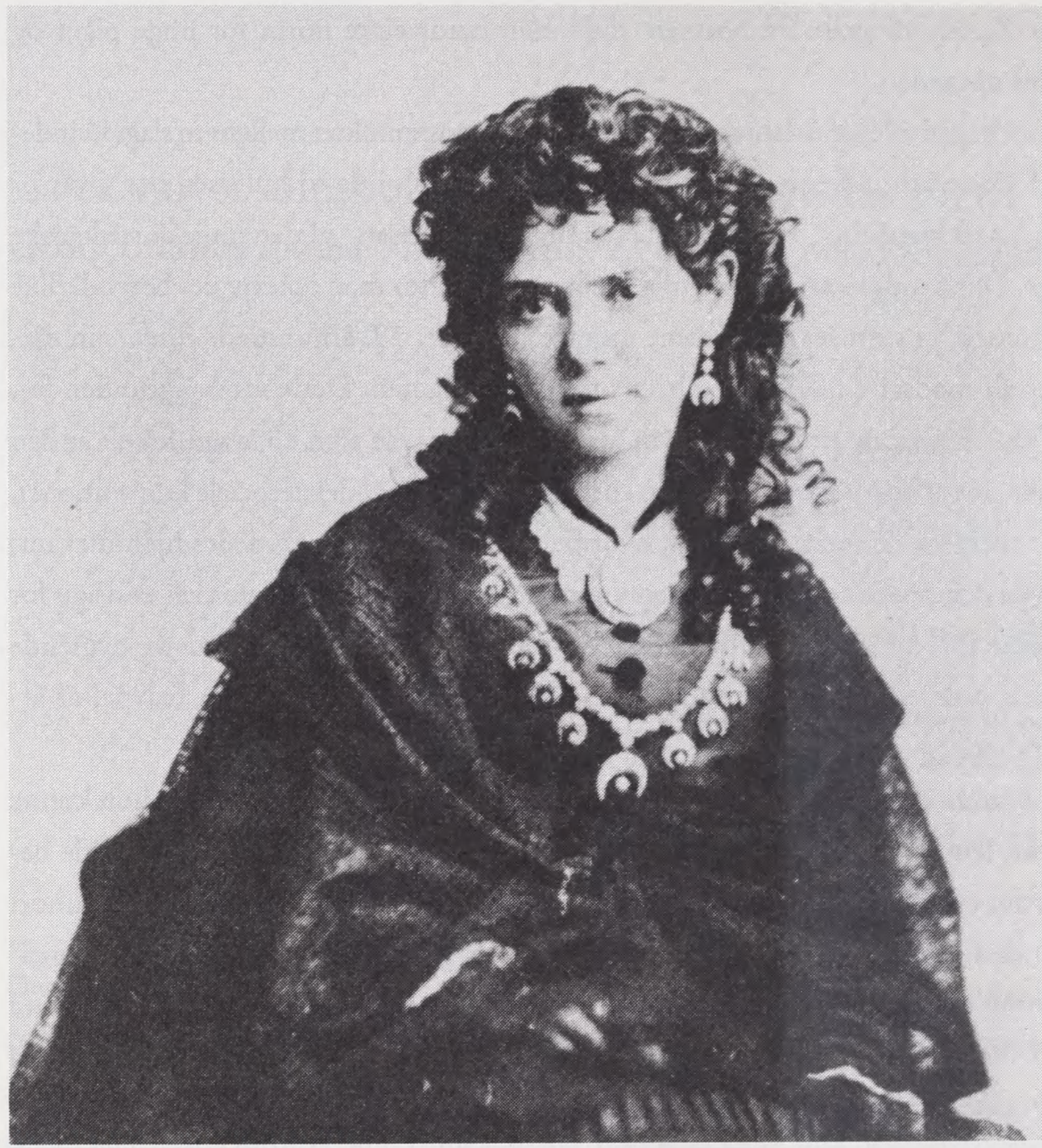

Med en ubeskrivelig Frihed og "Ledighed" i Væsen, som en af George Sands Heltinder, hvis en af dem havde et Ydre som en af Walter Scotts." (Breve til Foraldrene, s. 367).

den mandlige hovedperson i James's novelle, der som europæiseret amerikaner burde have haft alle forudsætninger for at forstå hende ret. Brandes, der med egne ord "aldrig havde set hendes lige før", tolkede hende rigtigt i løbet af et 17 dages bekendtskab. Brandes har med Vinnie Ream og James med Daisy Miller i hvert sit medium tegnet et vellignende portræt af "the American girl". Der er en slående lighed mellem dem. Selv om Brandes erklærede overfor Gertrud Rung: "Jeg kan ikke rose mig af, som de gode Romanforfattere og Dramatikere, at have skabt nogen Skikkelse. Jeg har som enhver uopfindsom kun levet mit eget Portræt," så er det en 
sandhed med modifikation, for med portrættet af Vinnie Ream har han levendegjort en skikkelse, så den i liv ikke står tilbage for James's fiktive portræt. Brandes portræt findes i flere versioner, det er tegnet både i breve til forældrene, broderen og venner og i en slutversion i Levned. Barndom og forste Ungdom, der er skrevet et kvart århundrede senere i 1905. Det oprindelige indtryk må imidlertid have stået stærkt, for der er ikke mange forskelle i versionerne, kun forskelle i tonen i brevene, f.eks. lidt mere mandepral overfor vennen Emil Petersen end overfor moderen. I læsningen af "the American girl" fulgte han sit eget råd, når det gjaldt læsning af bøger, nemlig at "Intet er dummere end at gaa efter Rubrikker". Selv om han var lige så uforberedt på fænomenet som det øvrige Europa, forstod han fordomsfrit, hvad han så og gengav det i sit eget medium.

Det var ikke alene "the American girl", Brandes blev konfronteret med i Vinnie Reams skikkelse, men også det beslægtede fænomen den professionelie kvindelige kunstner. Da frihed er forudsætningen for al kunstudøvelse, og da den amerikanske unge pige havde den i udstrakt grad, var det lettere for hende end det var for hendes europæiske medsøster at vælge at blive udøvende kunstner. I Rom var friheden for kunstnere større end noget andet sted, og det er baggrunden for, at man der i det 19. århundrede kunne møde et usædvanligt stort antal amerikanske kvindelige kunstnere, som især gjorde sig bemærkede inden for billedhuggerkunsten - hidtil anset for et "mandsfag" - snarere end inden for det mere forventelige medium malerkunsten. Denne set ud fra en europæisk synsvinkel "omvendte kvindetype", d.v.s den frigjorte unge pige uden chaperone, arbejdede vel at mærke som professionel kunstner og ikke som skik og brug var i Europa som dekorativ amatør, for som billedhuggeren William Wetmore Story forklarede: "A Yankee girl can do anything she pleases, walk alone, ride her horse alone, and laugh at their rules ...". "Yankee girl” kunne også være billedhugger og - så længe hun var ugift - færdes frit uden chaperone.

Lige fra Republikkens allerførste dage har amerikansk kunsthistorie været præget af kvindelige kunstnere i langt højere grad end tilfældet har været i Europa. Amerikas første professionelle billedhugger hed Patricia Wright. I perioden efter 1800 voksede behovet for nationalt forherligende kunst, man skulle hurtigst muligt opbygge en fælles fortid, og portrætter og statuer af den nye Republiks ledere blev stærkt efterspurgte, fordi den nye nation skulle profilere sig og havde brug for symbolske 


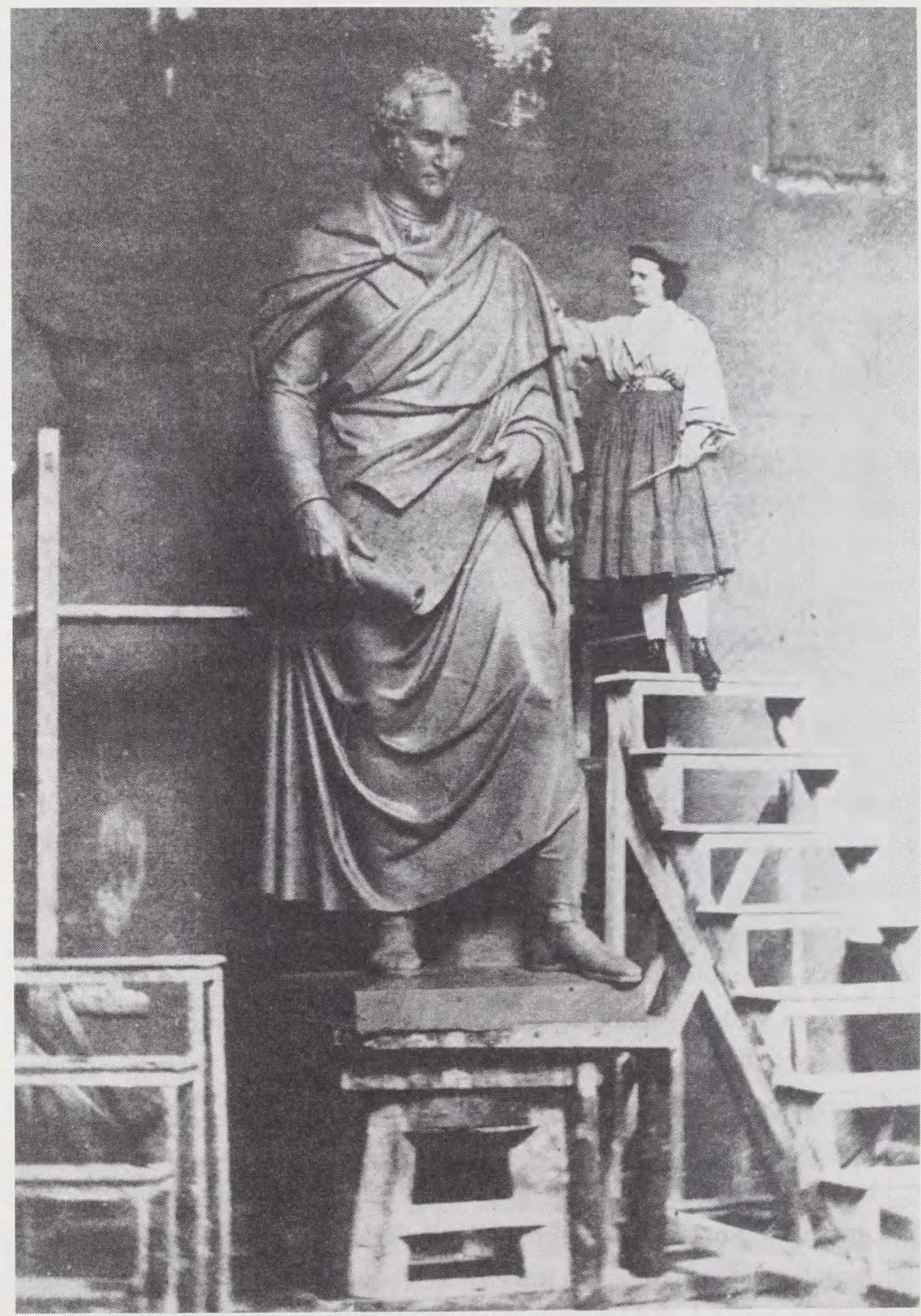

"Absurdly dwarfed but solemnly in control of her creation." Harriet Hosmer under arbejdet på statuen af senator Thomas Hart Benton. 
manifestationer i form af afbildninger af "illustrious leaders" - jo større jo bedre og gerne i stærkt idealiseret udgave, hvilke vil sige i neo-klassisk stil. George Washington måtte således finde sig i at blive iklædt antikt klædebon af landets første betydende billedhugger Horatio Greenough, og så sent som i 1861 udførte Harriet Hosmer som bestillingsopgave en bronzestatue $\mathrm{i}$ legemstørrelse af senator Thomas Hart Benton, hvor politikeren fra Missouri fremstår indhyllet i romersk toga.

Allerede fra århundredets begyndelse udvandrede amerikanske billedhuggere, mandlige såvel som kvindelige, til Rom, hvor betingelserne for at skabe de eftertragtede neo-klassiske skulpturer var bedst - og ikke mindst billigst. Her var billig marmor, lave leveomkostninger og "low-paid but highly skilled carvers". I spidsen gik Horatio Greenough, elev af Bertel Thorvaldsen, men omkring midten af århundredet slog en stor gruppe kvindelige billedhuggere sig ned omkring den spanske Trappe, "that strange sisterhood who at one time settled upon the seven hills, in a white Marmorean flock." (Henry James). Mest kendt af dem alle var Harriet Hosmer, hvis atelier var et yndet turistmål ikke alene for hendes landsmænd, men også for rige kunstsamlere og fyrster fra Europa. Selv prinsen af Wales, den senere Edward VII, aflagde besøg i hendes trestjernede atelier. Kulturturisme er ikke en opfindelse af nyere dato, den var allerede i det 19. århundredes Rom en blomstrende industri.

Arbejdende kunstneres studier var turistattraktioner, som man besøgte på linie med andre seværdigheder, og de stod opført og blev opdateret i datidens guidebøger:

"Studio visiting was still a social charade in the 1860 s. John Murray's guide, A Handbook of Rome and its Environs, continued to update the names and addresses of the painters and sculptors as well as their current works and the hours when they received visitors. "Hosmer, Miss (American)" could be found in her studio at 116 Via Margutta ..." (Sherwood, Dolly: Harriet Hosmer. American Sculptor 1830-1908. Lond. 1991).

Hosmer, Miss blev accepteret som en excentrisk original, og skal man tro kollegaen William Wetmore Story, var hun skabt efter Annie-Get-Your-Gun-modellen, for "she ran faster and could shoot straighter than any boy in Watertown". USA var det eneste land, der bidrog til kunstnermiljøet i Rom med et større kontingent af kvindelige billedhuggere. Andre medlemmer af "the Marmorean flock" var Anne Whitney, Emma Stebbins, Louisa Lander, Margaret Foley, Edmonia Lewis og Florence Freeman. 


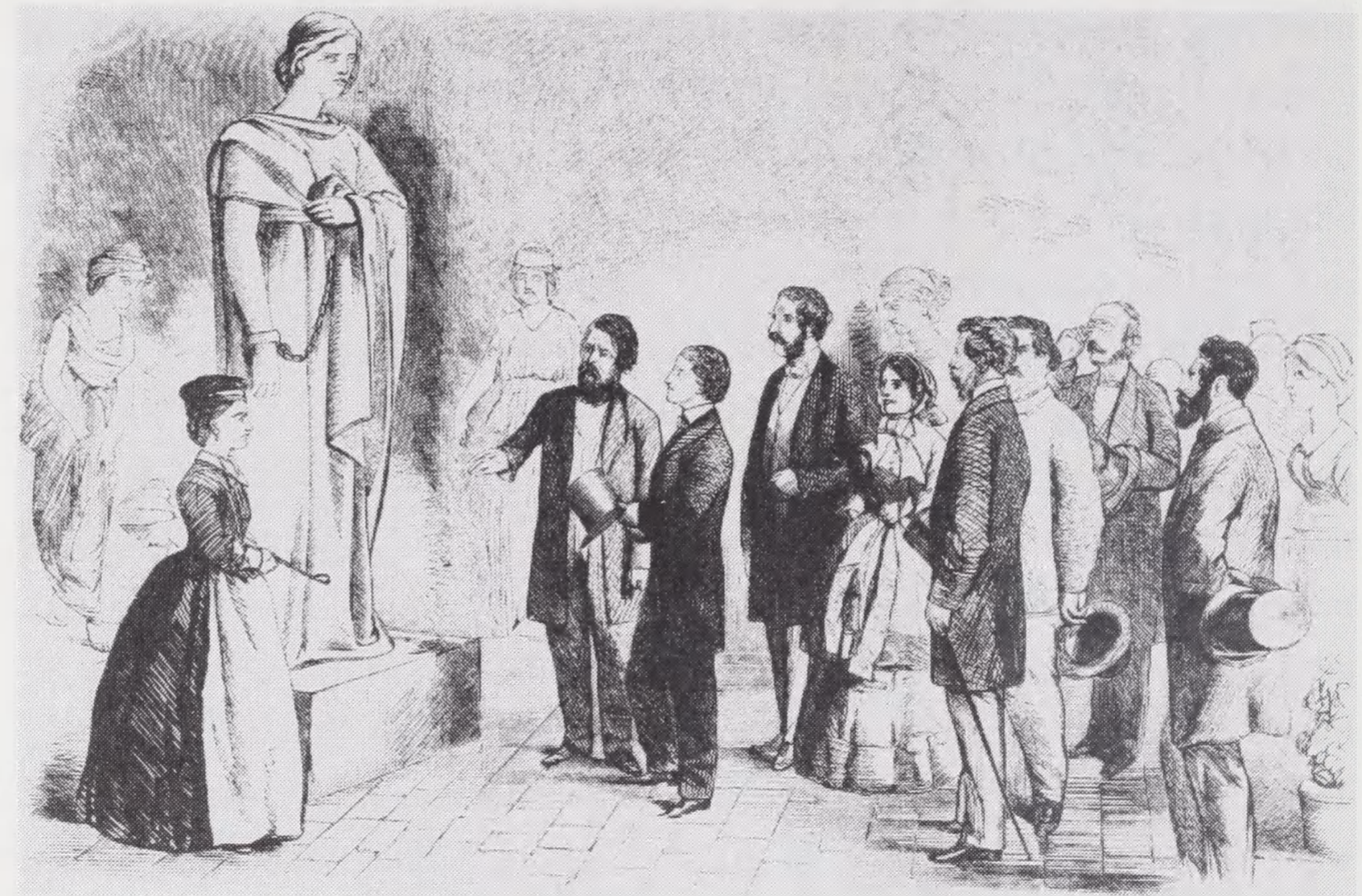

Prinsen af Wales, den senere Edward VII, med følge besøger Harriet Hosmers atelier i Rom 1859. "The talented artist herself receiving visitors generally from 1 to 2 o'clock." (John Murray: A Handbook of Rome).

Brandes mødte Vinnie Ream ganske uforberedt. Hun var meget anderledes end den excentriske Harriet Hosmer. Hun var ung, smuk og koket, og hendes eneste excentricitet bestod i en kunstnerisk jernvilje. Hendes liv havde indtil mødet med Brandes formet sig som det klassiske rags-to-riches eventyr, opfyldelsen af den amerikanske drøm om, at talentet i de uanede muligheders land altid ville komme til fuld udfoldelse, uanset hvilke forhindringer det måtte møde på sin vej. I Vinnie Reams tilfælde var forhindringerne tilsyneladende uoverstigelige, hendes fattige baggrund, hendes komplette mangel på uddannelse, og oveni hendes alder og hendes køn. Men alligevel var hun, da Brandes mødte hende, en etableret kunstner med eget atelier i Rom og med en bestillingsopgave fra den amerikanske stat på en statue af den myrdede præsident Lincoln til opstilling i Rotunden på Capitol. Alt sammen $i$ en alder af 23 år.

Hun var født i 1847 i Madison, Wisconsin. Hendes far var fra Pennsylvania, og hendes mors familie stammede fra Skotland. Familien flyttede først til Missouri, derefter til Arkansas, for endelig at slå sig ned i Washington, D.C., hvor hendes far 
fik en underordnet stilling i et regeringskontor. Vinnie fik samlet kun ca. 1 års skolegang, inden hun måtte tage et job som postassistent for at hjælpe familiens betrængte økonomi. Vendepunktet i hendes liv kom under et besøg hos billedhuggeren Clark Mills, hvis atelier lå i en fløj af Capitol. Her fandt hun sit medium. Efter besøget skyndte hun sig hjem og modellerede i ler hovedet af en indianerhøvding. I bedste eventyrstil skildrer hun selv hændelsesforløbet således:"I felt at once that I, too, could model and, taking the clay, in a few hours I produced a medallion of an Indian chief's head ... “ Medaljonen med indianerhøvdingens hoved blev starten på en formidabel karriere - en karriere skabt gennem rent talent suppleret med "a talent for being in the right place at the right time." Da hun viste Clark Mills medaljonen, antog han hende på stedet som elev, og hun begyndte nu at modellere portrætbuster af kendte politikere og andre celebriteter. Hendes arbejder blev så vel modtaget, at en kreds af politikere besluttede at skaffe hende mulighed for at lave en buste af præsident Lincoln selv. Hun var da 17 år. Trods en vis modstand mod planen fra præsidentens side - og især fra hans kones - gav han til slut efter, da han hørte, at hun var en fattig pige, for også hans liv havde været virkeliggørelsen af den amerikanske drøm om, at den begavede ukendte kunne nå toppen. I fem måneder sad han model for hende en halv time hver dag, og som Brandes skriver: "hun boede i hans hus hin 14. April 1865, da han blev myrdet."

Hendes buste af Lincoln blev meget beundret, så meget, at den blev anledningen til den centrale begivenhed i Vinnie Reams liv som kunstner, nemlig historien om Lincolnstatuen. Genfortalt lyder den totalt usandsynlig i europæiske øren, men er netop derfor arketypisk amerikansk: en ukendt 18-årig kvindelig billedhugger, komplet autodidakt, får af Kongressen overdraget kommissionen på udførelsen af en legemsstor marmorstatue af præsident Lincoln til opstilling på Capitol, altså på den officielle statue af den myrdede præsident. Selv i Amerika var en sådan beslutning selvfølgelig ikke lige populær i alle kredse. Brandes skildrer reaktionen i et brev til forældrene den 23. oktober, 1870: "Naturligvis fik hun, da hun vilde begynde derpaa, Alle imod sig og de fablede i alle Kroge om det skrækkeligt Ukvindelige $i$ at hun vilde være Billedhuggerinde, men hun paa sin Side satte ei mere Kraft ind end netop til at faae sin Krig igjennem, lod dem iøvrigt snakke, tog ingen Hævn over nogen Bagtalelse, viste selv de ilde sindede den største Velvillie og har nu efter sit eget Sigende ingen egentlige Fjender. Der udfordres til den Art Politik en Selv- 
beherskelse og en Art af Villie jeg aldrig har haft, men tillige en større Hiertensgodhed end jeg kan rose mig af."

Med kommissionen fulgte en bevilling på $\$ 10.000$, og det var med denne kommission i ryggen, at hun begav sig til Europa i 1869 , hvor hun opholdt sig i to år. På rejsen var hun ledsaget af sine forældre, som hun nu var forsørger for. Første stop på rejsen var Paris, hvor hun studerede hos Leon J.F. Bonnat, og her gentog eventyret sig, idet den unge ukendte kunstner fra Amerika fik lejlighed til at lave buster af både Gustave Doré og Père Hyacinthe. Da hun slog sig ned i Rom for at overføre statuen til marmor - rejsens hovedformål - blev hendes atelier hurtigt samlingssted for den internationale kunstnerkoloni, hvilket ikke forhindrede hende i foruden at fuldende arbejdet med Lincolnstatuen - også at få tid til at lave buster af berømtheder som f.eks. Franz Liszt og Kardinal Antonelli.

Det var dette utrolige fænomen Georg Brandes i 1870 mødte i en togkupe mellem Firenze og Rom. Hun var sammen med sine forældre på vej hjem fra Carrara, hvor hun havde overvåget statuens færdiggørelse i marmor inden dens indskibning til Amerika. Beretningen om Georg Brandes og Vinnie Ream falder i to dele, mødet i 1870 og "ikke-mødet" 40 år senere. Det første kaster især lys over ham, det andet over hende.

"I Aaret 1870-71 levede jeg sexten Maaneder i Træk i Paris, London, Schweiz og Italien. Alt, hvad jeg iagttog, gjorde i de Aar et heftigt Indtryk paa mig, og jeg opskrev Dag for Dag mine Oplevelser og Tanker”. Sådan skrev Brandes i Udenlandske Egne og Personligheder, Kbh. 1893. Det var i løbet af dette annus mirabilis, at han mødte Vinnie Ream, der, som han sagde, gjorde "et heftigt Indtryk" på ham, for netop i det år stod alle hans sanser vidåbne. Det var et heldigt tilfælde, der førte ham sammen med hende på rejsen til Rom, for han var blevet opholdt i Firenze længere end oprindelig beregnet: "Men denne Omstændighed blev meget heldig for mig. Thi uden den havde jeg ei giort et Bekendtskab, der har været mig til stor Glæde". Bekendtskabet præsenterede sig således: "Ved Middagstid træder ind i Vognen en ung Pige, øjensynligt engelsk eller nordamerikansk, med brune Øjne, brunt Haar, der falder i naturlige Lokker om Hovedet." Førsteindtrykket er hendes slående udseende: "Hun saa meget aparte (Walter Scottsk) ud og vakte en vis Opsigt ved sin Dragt og sit smukke Udvortes". Det vakte ikke mindre opsigt, at hendes forældre fulgte hende ydmygt, og at det var hende, der sørgede for dem, ikke vice versa. 


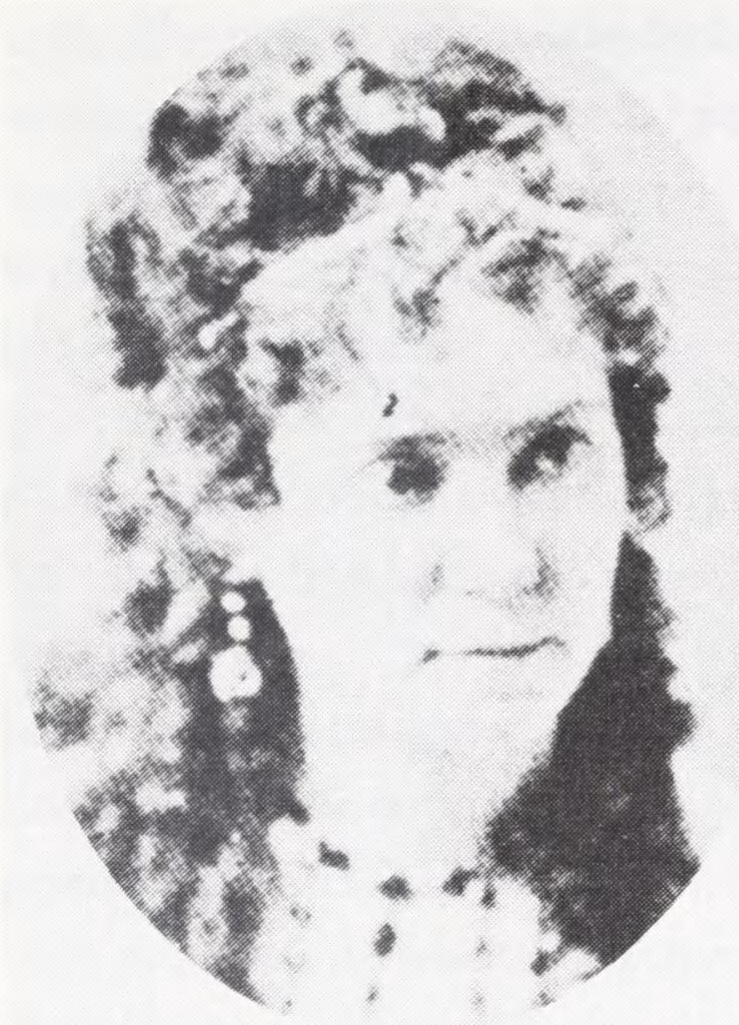

"Ved Middagstid træder ind i Waggonen en ung Pige, øiensynligt engelsk, med brune Øine, brune Krøller i fine Lokker om Hovedet ... Hun bærer en Reisedragt, derover en Guldkjæde og i hvert Øre har hun to Muslingskaller hængende under hinanden ...". (Breve til Foraldrene, s. 366).

Endelig og især vækker det forargelse og forbløffelse, at hun friskt og frejdigt indleder en samtale med en vildfremmed mand - in casu Georg Brandes: "Da hun fandt Behag $\mathrm{i}$ at samtale med mig, udbrød hun uden videre: "I will stay with you", sagde mig nogle Artigheder, og tog det Løfte af mig, at jeg vilde fortsætte Rejsen med hende til Rom." Hun erklærer således frimodigt sin tilfredshed med Brandes' selskab. I Europa hvor "a young man was not at liberty to speak to a young unmarried lady except under certain rarely occuring conditions," der tiltaler Vinnie Ream, en ung smuk amerikansk pige, uforfærdet en ung europæisk mand og giver sig spontant i snak med ham - tilmed i et tog, for som hendes amerikanske medsøster Daisy Miller forklarer Winterbourne: "I have never allowed a gentleman to dictate to me or to interfere with anything I do.” Brandes får her et lynkursus i the American girl.

Hendes første indtryk af ham var: "Jeg seer igjennem Ansigtet Charakteren, derfor vover jeg skjøndt fremmed at tale til Dem. De har en sjelden Intelligents og en stor Originalitet”. Hun betragter ham nøgternt med en billedhuggers øjne, men konklusionen er selvfølgelig ret så smigrende. Modstykket hertil, hans indtryk af hende, er ikke mindre smigrende, omend langt mere "litterært" i udtryksformen:

"Nu er det Besynderlige denne forbausende Sympathi hun følte for mig. Hun skrev mig sin Adresse op i Rom, bønfaldt mig om at komme hyppigt i disse 2 Uger hun alene kan blive her ... alt dette uden Exaltation med en ubeskrivelig Frihed og 
"Ledighed" i Væsen, som en af George Sands Heltinder, hvis en af dem havde et Ydre som en af Walter Scotts. Jeg vil ei negte jeg blev noget ør af alt dette. Saa kjørte jeg da for første Gang over den romerske Campagne i det yndige Maanelys med disse to brune Øjne stirrende ind i mine og i en Samtale, hvis Finhed, sympathetiske Forstaaelse og hele besynderlige Magi rørte mig paa en bestemt Maade, som jeg ikke erindrer at Noget har paavirket mig i mit Liv."

Med dette lille "prosadigt" præsenterer han hende for sine forældre. Det blev en samtale, der iflg. Brandes, hvis tidsangivelser varierer noget, kom til at vare fra "12 Middag til 10 1/2 Aften".

Omgivelsernes reaktion fik de på stedet. Modstykket til hendes åbenhed og frihed fandtes i samme kupe. Deres møde og samtale blev overvåget af en dansk kunstner og hans kone: "Ved Treni kom et dansk Ægtepar, en middelmaadig Kunstner og hans Kone, ind i Vognen og iagttog med national Forundring og Nysgerrighed Fortroligheden mellem den fremmede unge Pige og mig, om hvilken da ogsaa alle Skandinaver i Rom vidste Besked et Par Dage efter." Deres reaktion var uden rummelighed og frisind, det var småborgerskabets forargelse. Lillebyen var flyttet med, og Brandes lagde sig da også prompte ud med den skandinaviske kunstnerkoloni og bekræftede til overflod Vinnie Reams senere karakteristik af ham: "Hun har sagt mig adskillige slaende Ting om min Karakter og bl.A. det at jeg er et af de mest upolitiske Mennesker, hun har kjendt."

De første 17 dage i Rom tilbragte Brandes således ikke med sightseeing, men så meget som muligt i Vinnie Reams selskab og kom dermed let ud over sit eget rejsedilemma, beskrevet i et brev til vennen Hans Brøchner: "Jeg strander bestandig paa det Dilemma, at det mest Interessante ved Rejsen er det den enkelte alene kan opleve, medens det, man oplever i Fællesskab med andre, Synet af Monumenter og deslige, mest er tusinde Gange beskrevet." Vinnie Reams atelier var samlingssted for et mondænt publikum, og selv i disse hektiske opbrudsuger "modtog hun daglig Besøg af mellem seksten og fem og tyve Personer." Men hun styrede sit liv og sin karriere med jernhånd: "Jeg har aldrig hos noget kvindeligt Væsen og i saa fint et Legeme truffet en Villie som hendes." Hendes arbejdsdisciplin var formidabel, hun overvågede hjemsendelsen af Lincolnstatuen, færdiggjorde busten af den frygtede kardinal Antonelli, sad model for den amerikanske maler George P.A. Healey, der malede hendes portræt, styrede forældrenes husholdning og fik daglig tid til "at afse 
et Par Timer til mig, enten til en Spadseretur eller til Vandring paa de forskellige Gallerier." Brandes måtte pænt kende sin plads.

Alligevel "har hun hidtil næsten været mit eneste Studium i Rom. Og virkelig et lønnende. Mangen Gang føler jeg mig som et Fæ ved Siden af hende, og tilmed er hun et Væsen, som det var aldeles umuligt at finde hjemme eller rimeligvis overhovedet andensteds end i Nordamerika."

Mødet med Vinnie Ream og deres 17 dages samvær skulle vise sig at være "lønnende" på flere områder. Først og fremmest lærte han selvfølgelig "the American girl" at kende ("en Natur, hvis Mage jeg ikke tidligere har kjendt"), hvad der kom ham til gode mange år senere på den store Amerikarejse, hvor han ikke som så mange mødte den ny verden med "det europxiske Magasin af stereotype Talemaader og nedsaltet Vrøvl".

Det var dog ikke alene amerikanske kvinder, men også kvinder generelt og kvindelige kunstnere specielt der indgik i uddannelsen. Han indrømmer blankt, at da han mødte Vinnie Ream, havde han samme fordomme som de italienske mænd i kupeen: "Jeg forstod hende ei i Begyndelsen, Fæ som jeg er, Skoledreng som jeg er, havde jeg en Læst for alle Kvinder og naturligvis alle Slags gemene Formodninger paa rede Haand. Det hører jo til." Og selv om han i starten vanemæssigt koketterer med sin "Erobring" over for vennen Emil Petersen og skriver, at han "i Aften har et Stævnemøde med en amerikansk Billedhuggerinde, der er blevet forlibt i mig," så er den skildring af forløbet redigeret efter modtageren, for han erkender snart, at det ikke - for nogen af dem - drejer sig om forelskelse. Vinnie Ream var ikke nogen erobring, og hun var heller ikke forlibt $\mathrm{i}$ ham, hvad han straks indrømmer over for moderen: "Det menneskelige Sprog er saa fattigt, og saa dumt. Jeg har aldrig været forelsket i Vinnie, og dog troe de fleste Mennesker dette nødvendigt, naar de høre slige Udtryk som dem, jeg nu bruger. Men jeg holder af hende som af en Ven, en inderlig kjær Kammerat, en Aand, der er i Slægt med min ... Hun har endelig engang igjen vist mig et helt Menneske." Var de ikke forelskede i hinanden, så var de begge forelskede i den inspiration, de gav hinanden: "Hvad faaer jeg af Dem?" sagde jeg. "Inspiration" svarte hun leende. Det var nøgen Sandhed." Selv om Brandes sommetider hænger det op med guirlander, var der kun tale om et overensstemmelsesforhold, men mødet var for begge en skelsættende personlig oplevelse. For Vinnie Ream kom det senere til at stå som et af højdepunkterne i hendes liv 
som kunstner, og da hun i slutningen af sit liv gennemlevede en svær personlig krise, blev Brandes identificeret med det tabte kunstens paradis, hvad man indirekte kan læse ud af den korrespondance, der findes på Det kongelige Bibliotek.

Endelig lærte han - igen med egne ord - "hvor bornert jeg selv er", for ikke alene kvindeklicheer men også standsklicheer var tilbøjelige til at visne i hendes selskab. $\mathrm{Da}$ han en dag $\mathrm{i}$ hendes atelier mødte "en simpel Mand (Italiener)" og behandlede ham nedladende, fordi "jeg kunde paa godt Dansk ei ret overtale mig til at betragte ham som Gentleman", irettesatte hun ham meget kontant: "Tal smukt med ham og som til en Gentleman, for det er han, han kan fortræffeligt 4 Sprog, det er en talentfuld Mand. Vi Amerikanere see ei paa Stillingen men paa Manden, og han gjør sin Stilling Ære." Heller ikke vanetænkning trivedes i hendes nærhed. En dag var det lykkedes hende at slæbe ham med

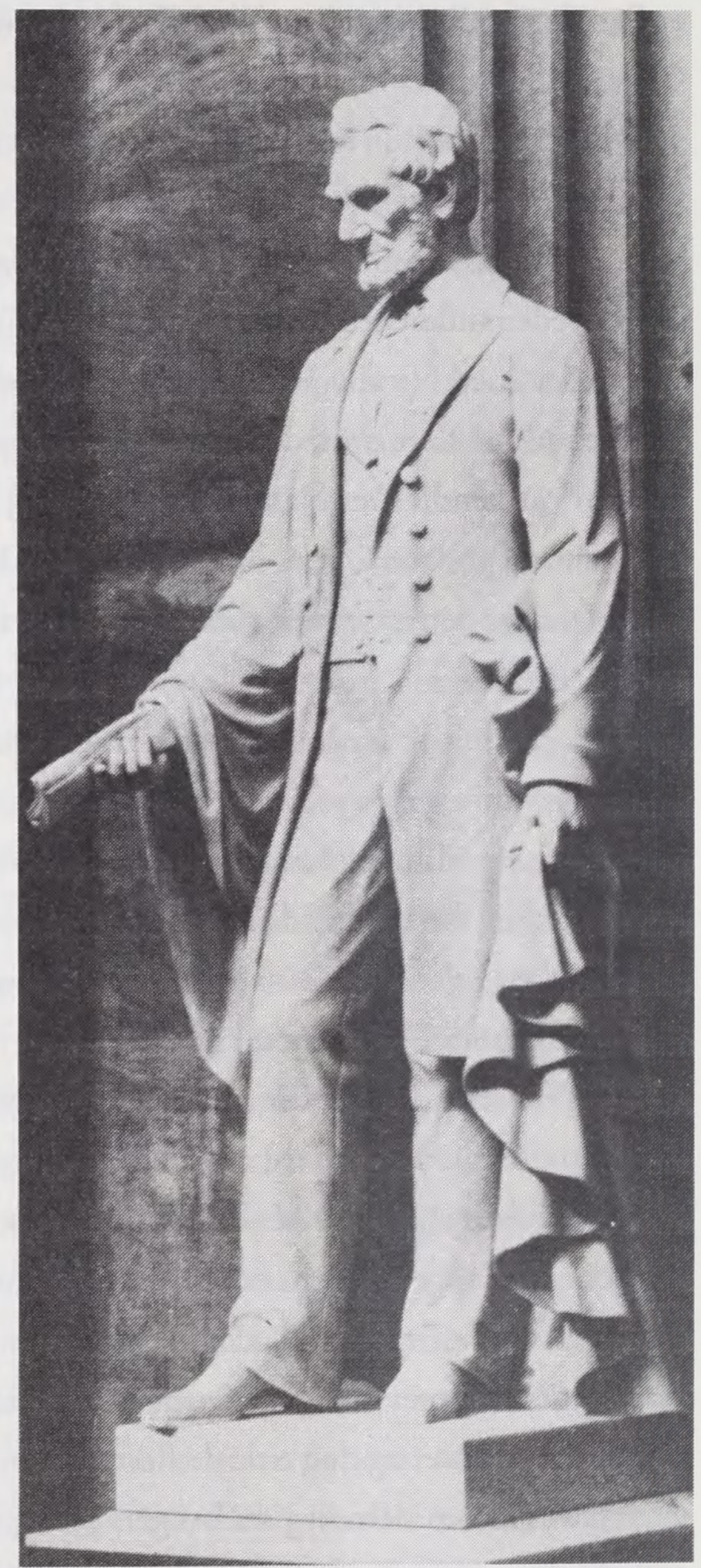

Abraham Lincoln. Capitol, Washington. "Jeg synes ei helt godt om den." til gudstjeneste i det amerikanske kapel - i sig selv ikke nogen ringe bedrift. Her deltog hun fromt og opmærksomt i salmesangen og lyttede tilsyneladende henført til prædikenen. Da de gik ud, forholdt Brandes sig tavs, "da jeg ei rigtig vidste, om ei Vinnie var noget bevæget; thi hun sang paa Slutningen meget følsomt, men hun tog blot min Arm og sagde disse 


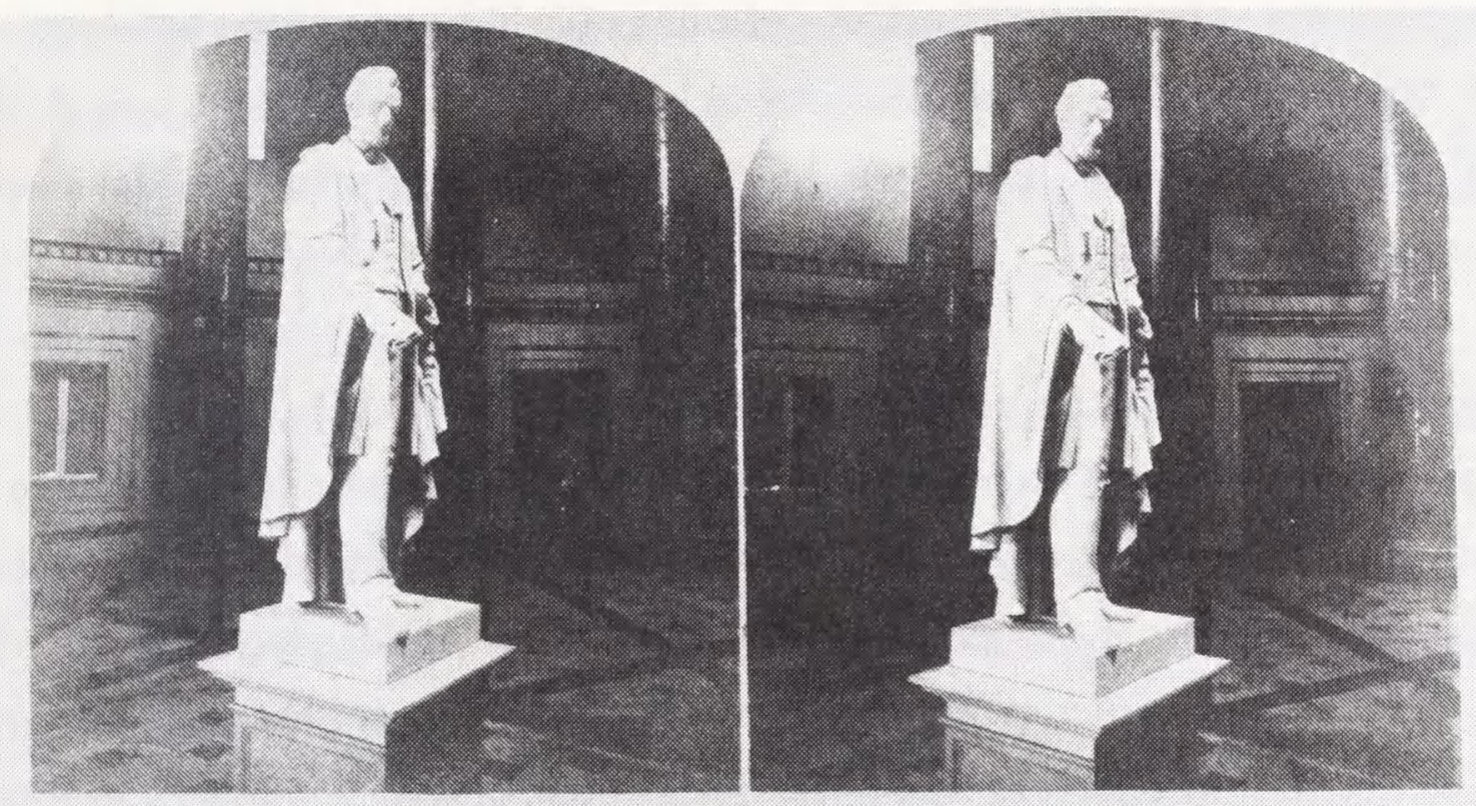

Abraham Lincoln. Stereoskopbillede. Kort- og Billedafdelingen.

gyldne Ord "den Præst er det stupideste Asen af en Præst jeg endnu har kjendt, men det er morsomt at synge." Over for moderen kunne han konkludere: "I ethvert Fald er mit Bekjendtskab med hende en meget interessant Skole", for hun er "baade ved Opdragelse og ved sin Stilling som Konstnerinde ført til at betragte næsten alle Baand som Fordomme".

Kun på eet punkt lod Brandes sig ikke rive med af sin begejstring. Han går ikke på kompromis som kritiker og underkaster hendes kunst samme bedømmelse som al anden kunst uden vennerabat: "Jeg saa idag en stor Photographie af hendes Statue af Lincoln. Jeg synes ei helt om den men jeg vil nu se nogle af hendes Phantasiearbejder. "Han bedømmer hendes kunst uden overdreven begejstring, men modsat mange andre kritikere, frakender han hende heller ikke talent ud fra devisen: når jeg ikke kan lide det, kan det ikke være kunst. "Jeg har seet for lidt af hende til at have en klar Forestilling om Betydningen af hendes Talent, men jeg har aldrig hos noget kvindeligt Væsen og i saa fint et Legeme truffet en Villie som hendes." Hans beundring for kvinden slørede ikke hans kritiske sans over for kunstneren, og han forligte sig aldrig helt med hendes kunst. "Selv da jeg havde seet en Del til hendes Kunst, kunde jeg ikke helt føle mig tiltalt af hendes Talent, der undertiden ytrede sig mindre plastisk end malerisk og var tilbøjeligt til følsomme Virkemidler. Men hun var en sand Kunstnerinde." Hvad han især reagerede mod var den sentimentalitet i udtrykket, som senere kommer til forstærket udtryk i hendes breve. Han 
gjorde dog een undtagelse: "Hun har et mærkværdigt Talent til Buster og Medailloner". Han beundrede både hendes buste af Kardinal Antonelli, "der bliver aldeles fortrinlig" og den buste hun havde lavet i Paris af Père Hyacinthe, "der er paa engang sand og poetisk".

\section{USA 1906 - 1915: The American matron}

Anden halvdel af historien om Brandes og Vinnie Ream udspiller sig mange år senere, nemlig i perioden 1906-1915. Den direkte anledning til at forbindelsen blev genoptaget var udgivelsen af den engelske udgave af Brandes Levned i 1906 med det smukke portræt af Vinnie Ream. Det første brev fra hende er udateret, men det er klart inspireret af læsningen af hans bog.

Da Vinnie Ream efter de 17 gyldne dage i Rom rejste tilbage til USA, afsluttede Brandes kapitlet om mødet således: "En Dør aabnes, en Dør lukkes, og man ser ikke hinanden mer paa denne Jord ..." Hans ord kom til at holde stik. De så ikke hinanden mere, men der blev alligevel skrevet endnu et kapitel, og det kapitel fortæller om Vinnie Reams videre skæbne. Ved afrejsen fra Rom skrev han: "gid den fordømte Verden ikke maa flaae eller æde hende, gid hun maa kunne døe engang med samme klare Pande, hvormed jeg har seet hende." Hans ønske gik ikke i opfyldelse.

Hun kom tilbage fra Europa til afsløringen af Lincolnstatuen på Capitol. Det var i 1871 . Nu strømmede opgaverne ind. Den største og vigtigste var udførelsen af en bronzestatue af admiral David C. Farragut, som Kongressen havde bevilget \$ 25.000 til. Vinnie Ream vandt denne komission i skarp konkurrence med en lang række af tidens kendteste billedhuggere som f.eks. William Wetmore Story, T.Q.A. Ward, m.fl. Statuen blev afsløret i 1876 på Farragut Square. Det var under arbejdet på denne, at hun mødte sin tilkommende mand løjtnant, senere brigadegeneral, Richard Leveridge Hoxie, der blev præsenteret for hende af General Sherman. Med giftermålet i 1878 forvandledes "the American girl" til "the American matron", og hvad det indebar, kan man læse ud af artiklen om hende i Charlotte Streifer Rubinstein's kunsthistorie American Women Artists. N.Y. 1982:

"Her home in Farragut Square became a center of Washington social life. She had a son, and deferring to her husband's wishes, gave up sculpture and became a social leader and charity worker, playing the harp at informal gatherings in her home".

Den professionelle billedhugger var blevet forvandlet til amatørharpenist. 
Så tidligt som i 1893 udkom i Amerika noget så avanceret som et biografisk kvindeleksikon med den pompøse titel Woman of the Century; fourteen hundredseventy biographical sketches accompanied by portraits of leading American women in all walks of life. Det var redigeret af Frances E. Willard og Mary A. Livermore og forordet indeholdt følgende programerklæring:

"Among all cyclopedias and books about famous women, this is intended to be unique and to supply a vacant niche in the reference library. The nineteenth century is woman's century. Since time began no other era has witnessed so many and so great changes in the development of her character and gifts and in the multiplication of opportunities for their application."

Oven på denne fanfare er det med en vis forventning, at man slår op på Vinnie Reams navn, da hun som berømt billedhuggerinde må være selvskreven blandt de 1470. Man finder hende imidlertid ikke - og dog er hun der alligevel, for kunstneren er blevet forvandlet til brigadegeneralens frue med det resultat, at man skal slå op på Vinnie Hoxie. Da der ingen henvisning er, skal man således på forhånd kende brigadegeneralens navn, for at finde frem til hende blandt århundredets kvinder. De store forandringer, der skulle være sket i kvindens århundredet er heller ikke lette at få øje på, når man i artiklen om hende kan læse: "Mrs. Hoxie, at the earnest request of her husband, now models only for love, and not for money." Det lyder nærmest som gravskriften ikke alene over "the American girl", men især over kunstneren Vinnie Ream, for kunst skulle altså stadig være ubetalt hobby for at kunne accepteres inden for ægteskabets rammer. Så sent som i 1942 måtte den selvstændige amerikanske pige som Brandes oplevede i 1870, finde sig i at blive opført under sin langt mindre kendte mands navn i Who Was Who in America - nu dog med en henvisning fra Vinnie Ream.

Vinnie Reams skæbne adskiller sig mærkbart fra den skæbne, som de øvrige medlemmer af "the Marmoreal flock" fik, fordi hun som den eneste frivilligt valgte at opgive sin professionelle status til fordel for amatørstatus. Hun var imidlertid kunstner nok til ikke i længden at kunne behandle sin kunst som dekorativ hobby. Det skulle vise sig at have sine omkostninger. Fortrængningerne var medvirkende til det nervesammenbrud hun fik mange år senere, og som fik hende til at forlade harpen og vende tilbage til "her profession".

På Det kongelige Bibliotek findes en lille korrespondance, der kaster lys over 
hendes skæbne efter tilbagekomsten fra Italien. Den består af fire breve fra hende selv til Brandes, hvoraf de to første er skrevet i 1870, det næste i 1906, og det sidste er dateret den 2. august, $1914 \mathrm{og}$ blev ikke afsendt af hende selv men af hendes mand, der fandt det blandt hendes efterladte papirer. Derudover indeholder korrespondancen tre breve fra hendes mand til Brandes fra henholdsvis 1909, 1914 og 1915 - det sidste skrevet umiddelbart efter hendes død.

Ligesom mødet med Vinnie Ream vendte op og ned på Brandes' begreber om kvinder og kunstnere, således vender læsningen af Vinnie Reams og især af hendes mands breve op og ned på vore vanebegreber om den gifte kvindes stilling i Amerika, for helt så firkantet, som den er fremstillet ovenfor, var den ikke. For den moderne kvindelige læser er Hoxie skurken, men brevene til Brandes reviderer klichebilledet af ham.

De to første breve er skrevet allerede i 1870, og tonen heri er mærkbart anderledes end i de senere. Den unge Vinnie Ream herser selvsikkert med Brandes. Det første er en kort besked - i bydeform - om at han skal komme hen til hendes atelier næste dag kl. 12, for at de kan gå på udstilling sammen. Det næste - dateret 16. november, 1870 - blev skrevet på hjemrejsen fra Bruxelles. Vi er nu i fotoudvekslingens tidsalder, og hun beklager, at hun ikke, som lovet, har kunnet sende ham fotografier af Lincolnstatuen, men skriver, at hun i stedet sender et billede af et af sine tidligste værker, nemlig en buste af senator Thaddeus Stevens. Tonen er uforandret bydende: "I will expect to receive a letter from you at Washington - I will be very much pleased if you will write me fully and entirely your views and impressions of Rome - its surroundings - its pictures and statues - I am serious in this request, and I know you will not refuse to grant any request of mine." Det er et vennebrev skrevet af en noget "bossy" ven.

Da Brandes Levned udkom på engelsk i 1906 (Reminiscences of my Childhood and Youth), skrev venner og bekendte fra nær og fjern til hende for at henlede hendes opmærksomhed på det smukke portræt, han havde tegnet af hende deri. Hun genoptog straks korrespondancen og skrev til ham og udtrykte ønsket om at gense ham, men hendes formulering af ønsket har sikkert ikke fremmet opfyldelsen. "now I feel as if I must see you once again, but if not here, we will meet at the end of the long journey awaiting us." Ønsket om et møde i det hinsides har givetvis ikke appelleret til Brandes. 
Et interval på 36 år skiller de to første breve fra dette brev, der er dateret d. 27 november, 1906. Tonen heri er blevet en helt anden. "My dear friend" er udskiftet med "Dear George Brandes", og den indledende sætning viser forandringen: ”To think that you should still remember little me!" Hun opsummerer sit livsforløb i de forløbne år således: "My life has been a romance, pieturesque in every detail, and I know you will be glad to hear my lines have fallen in pleasant faces." Det er set med en billedhuggers øjne. Nøglesætningen i brevet er: "After making the Lincoln and Farragut statues both ordered by the U.S. Govt, I married and Col Hoxie forbade my working." At hendes liv imidlertid ikke havde været lutter "romance", viser en senere passage: "Three years ago I had a most serious attack of heart trouble and the Army Surgeons thought it was due to suppression of feeling - my wanting to work and not being allowed to do so". "Suppression of feeling" synes en overraskende moderne diagnose for militærlægerne at stille, men måske er det vore fordomme, der får os til at undre os over den. Det var netop fortrængningen af kunstneren Vinnie Ream, der havde ført til det, vi i dag ville betegne som et nervesammenbrud. Hendes mand accepterede militærlægernes diagnose og drog straks konsekvensen heraf: "Col Hoxie became very much frightened, and begging me to "try and pull through for his sake" he told me again and again that if I would try and live, I might resume my work." Han lod opføre "a splendid studio" i forbindelse med deres hjem, og i dette udførte hun nu endnu to "heroic-sized" bronzestatuer af henholdsvis Ezra Cornell, grundlæggeren af Cornell University, og af guvernør Samuel Kirkwood fra Iowa til opstilling i Statuary Hall på Capitol, hvor hver enkelt stat havde lov til at opstille to statuer, samt en "fantasistatue" af den lærde Cherokee indianer Sequoya. Hun nåede ikke at gøre den færdig, og den blev fuldendt efter hendes død af billedhuggeren George Zolnay og står i dag på Capitol, hvad der gør Vinnie Ream til den eneste kvindelige billedhugger, der er repræsenteret ved tre statuer i Statuary Hall.

Vinnie Reams kunst bevæger sig mellem det meget konkrete, buster og statuer af politikere og statsmænd, og det meget abstrakte, - "fantasistatuer" af begreber eller personer. Eksempler på det første er Lincoln- og Farragutstatuerne, samtidspersoner af genkendelig lighed, men også lettere "heroiserede". Til den anden kategori hører f.eks. "The Spirit of Carnival”, "The West” og "fantasipersoner" som "Dying Standard Bearer", "Sappho", "Spartacus" og "Sequoyah". Både i politikerstatuerne 
og i det som Brandes kalder hendes "Phantasie-Arbejder", idealiserer hun det konkrete og konkretiserer det abstrakte. Der er ikke nogen mellemvej, og alle hendes motiver fortolkes inden for rammerne af nyklassisk udtryksform.

Det sidste brev fra hende er skrevet i Iowa City den 23.8.1914, mens Brandes endnu var i America, og heri beklager hun meget, at de ikke fik anledning til at mødes ("the tyranny of Fate"), for da Brandes var i Washington, var de i Iowa. Brevet er holdt i en lettere eksalteret tone med rigelig brug af udråbstegn. Hendes mand fandt det efter hendes død og sendte det til Brandes. I brevet udtrykker hun ønsket om, at Brandes må møde hendes mand "to cement the friendship which now is so earnest and congenial."

Selv om Brandes aldrig mødte "Colonel Hoxie", så etableredes en brevforbindelse mellem dem så tidligt som i 1909 - 5 år før Amerikarejsen, og der er noget, der tyder på, at hun havde ret $i$, at hendes mand var en mere kongenial brevpartnur, end hun selv var. Den indirekte anledning til korrespondancen var Brandes' portræt i $R e$ -

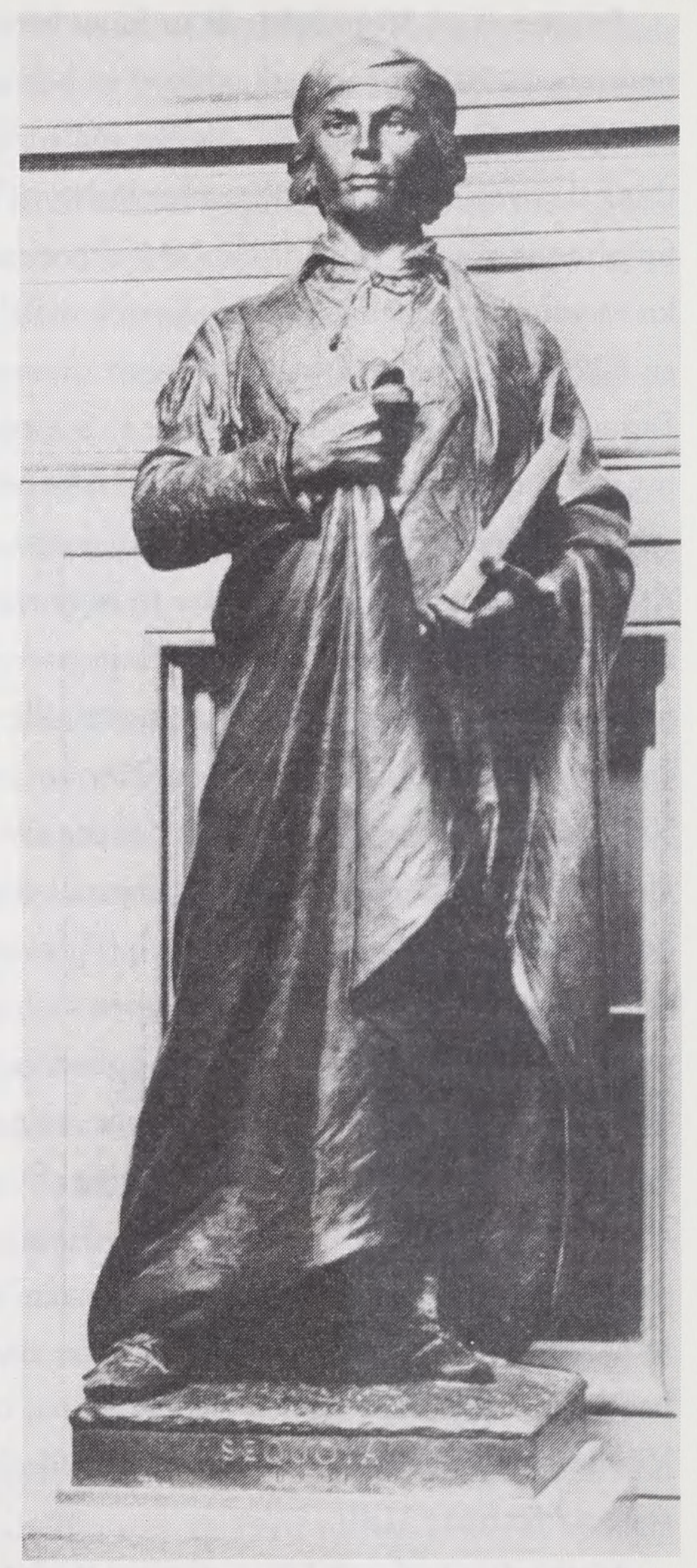

Sequoya, den lærde Cherokee-indianer (1770-1843). Statuen er Vinnie Reams sidste arbejde. Efter hendes død blev den udført i bronze af billedhuggeren George Zolnay. Står på Capitol. 
collections, men den direkte var, at Hoxie ønskede at sende Brandes “a souvenir of the artist life of Vinnie Ream. It is a compilation of letters and records which have survived the wreck of travel and change in army life ... you will find in this the impressions of two distinguished men, one of whom had known her for seventeen days, and the other for sixteen years." Der er en klar kvalitetsforskel mellem hans klare og kontante stil og hendes mere følelsesladede og sentimentale. Hoxie genkender og bekræfter Brandes ungdomsportræt af hende:

"After thirty years of the intimacy of married life I recognise in your clear and keen analysis the child-woman vividly pictured as I know her. And she is unchanged in mind and heart and joyous inspiration. The eyes and the voice and the touch of her hand, the imperious will and the quick sympathy are just as of old. They will survive to the end. And she is now as busy as ever with Art. For twenty years I suppressed it, partly because I was selfish, but mainly because of the envy, hatred, malice and all uncharitableness that pursue succes, - "the cruel world that rends and devours" - then came a nearly fatal illness, and the physicians told me that the repression was eating out her heart. I revived her by the promise of a studio. Now she has happiness - and I share it with her, - health and strength and boundless energy."

Når man læser denne version af forløbet, er det lidt svært at udslynge det rituelle "mandschauvinist". Han indrømmer blankt, at den oprindelige indgriben fra hans side, omend velment, var misforstået, og at den delvis skete af egoistiske grunde, men hovedårsagen dertil var det benhårde forretningsklima, der er succesdyrkelsens bagside i USA, den skyldtes først og fremmest "the envy, malice and all uncharitableness that pursue success." Meget stærke ord i en amerikaners mund, hvor det positive udtryk altid foretrækkes frem for det negative. Man får her et billede af baggrunden for hans indgriben, der ikke rigtig stemmer overens med det billede, man får ved læsningen af biografiske artikler om hendes liv. For helt at forstå den, må man også forstå den rolle, som "business" spillede i USA ved århundredets slutning.

Den frigjorte "American girl” kunne gøre alt, så længe hun ikke trådte inden for i penge- og forretningsverdenen. Når økonomiske interesser stod på spil, blev der ikke givet nogen pardon - heller ikke til unge kvindelige kunstnere. Kunsten i USA var fuldt privatiseret, og de måtte kæmpe på lige fod med mænd om kommissionerne 
og blev i kampens hede udsat for alle de "dirty tricks", som et frit marked åbner mulighed for. Alle offentlige kommissioner blev vundet ved konkurrence, og metoderne var undertiden mafiaagtige. I kampen om at opnå dem benyttedes deres køn ubønhørligt mod dem. På det område herskede ingen kønsdiskrimination.

At Hoxie's bekymringer derfor var yderst velbegrundede, er der mange gode eksempler på i det 19. århundredes kunsthistorie. Angrebenes styrke var ligefrem proportional med succesens størrelse, og derfor ramte de især tidens betydeligste kunstnere. De to kendteste kvindelige billedhuggere var Harriet Hosmer og Anne Whitney. Harriet Hosmer havde i Rom været elev hos den kendte engelske billedhugger John Gibson, og de mange britiske gæster, der i denne periode aflagde besøg i hans atelier, så samtidig hendes arbejder med det resultat, at hun fik mange bestillingsopgaver fra dem. I England fik hun hurtigt jalousien at føle. Da hendes hovedværk "Zenobia in Chains" fra 1859 blev udstillet i London, blev det mere end antydet af flere engelske journalister, at hun udgav statuen som sin egen, selv om den i virkeligheden var lavet af hendes lærer John Gibson.

Harriet Hosmer svarede øjeblikkelig igen med en retssag for bagvaskelse og vandt den. I USA kom Vinnie Ream ud for en lignende oplevelse, da hendes statue af Abraham Lincoln i 1871 blev afsløret på Capitol. Også her blev der snakket i krogene om, at hendes "studio assistants" (mandlige) sikkert havde lavet det meste af arbejdet, mens hun selv havde "flitted about Rome receiving the attentions of cardinals and other dignitaries." Hun svarede ikke selv igen, men hendes mere krigeriske kollega Harriet Hosmer skrev fra Rom et åbent brev til New York Tribune, hvori hun erklærede, at hun ud fra sit personlige kendskab til Vinnie Ream kunne bevidne, at hun var "as much entitled to the credit of her work as any artist I know", og at hun ud fra sit mangeårige kendskab til Rom ligeledes kunne bevidne, at "cardinals were not inclined to flit about with young ladies." Anne Whitney kom på hjemmebane ud for en endnu mere diskriminerende behandling end Vinnie Ream gjorde. I 1877 vandt hun en konkurrence om udførelsen af en statue af Charles Sumner, den kendte forkæmper for slaveriets ophævelse fra Massachussets. Bidragene til konkurrencen blev indleveret anonymt. Da dommerne for sent erfarede, at vinderen var af hunkøn, blev kommissionen frataget hende og i stedet givet til Thomas Ball, hvis køn var politisk korrekt. 7 år senere, da Anne Whitney var 81 år gammel, blev hendes statue støbt i bronze og opstillet på Harvard Square, hvor den står den dag 
Relief af Georg Brandes. Udført i bronze af den engelske billedhuggerinde Mary Lintner

Maquarie for The Royal Society of Literature.

1913. Det kongelige Bibliotek.

Brandes sad model for hende to gange under sit Londonophold i november/december 1913.

I samme periode blev han portrætteret af to amerikanske kunstnere, nemlig fotografen Alvin Langdon Coburn og billedhuggeren Jo Davidson. (Jvf. Magasin, 6. årg. nr. 4, 1992 og 5. årg. nr. 1, 1990).

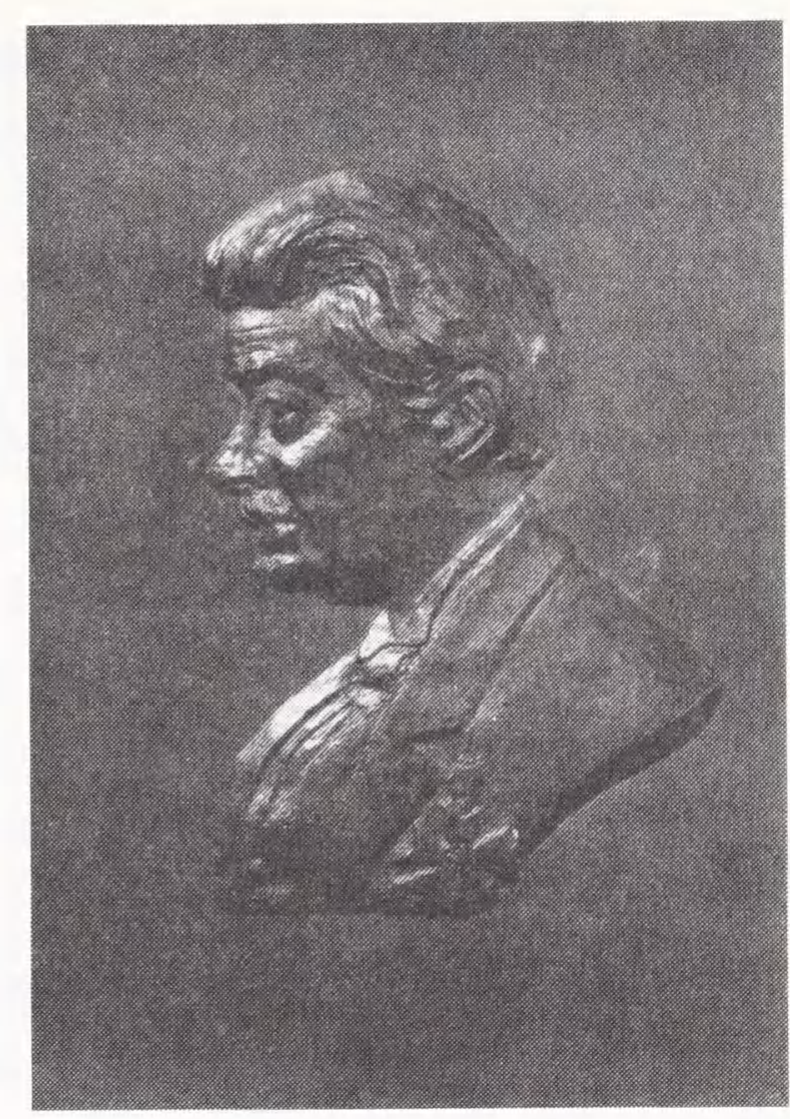

i dag foran den gamle Harvard Law School. William Wetmore Story, den mest indflydelsesrige i kredsen af amerikanske billedhuggere i Rom, opsummerede med vanlig urbanitet den gængse holdning til kvinder i kunstnerkredse: "Women are the most charming and delightful creatures in the world. I really don't know what we should do without them."

Det var dette klima, Vinnie Ream som ung succesrig kunstner vendte hjem til fra ltalien og på den baggrund er det ikke helt tilfældigt, at den mest uforbeholdne ros, hun fik af sine landsmænd, kom fra en kunstner, der arbejdede inden for et andet medium, nemlig malerkunsten, og som derfor ikke kunne føle sig truet af hende. George Healy, periodens kendteste portrætmaler, tøvede ikke med at give udtryk for sin beundring for hendes kunst over for Brandes, der gengiver hans ord $i$ et brev til forældrene, skrevet 30.10.1870:

"Jeg var igaar hos den amerikanske Portraitmaler Mr. Healy for at see Vinnie Reams Portrait. Det er smukt og friskt men der burde være gjort meget mere ud af det. Jeg vilde høre hans Mening om hendes Evner. Jeg sagde prøvende: "Troer De hun har en god Carriere for sig?" En god Carriere! sagde han, en stor, en stor. Og ikke for sig i den Betydning, at den nu først skal skabes. Hendes Lykke er gjort." Jeg sagde: "Hun har kun studeret 5 Aar". "Hun har Genie, sagde han, og saa er hele 
Resten det Samme.” Jeg blev meget fornøiet over dette.”

Da Vinnie Ream mødte sin tilkommende mand, havde hun netop vundet kommissionen på Farragut statuen efter en blodig kamp med de sædvanlige beskyldninger for at have opnået den attraktive bestilling ved "Women's wiles", og der er måske ikke så meget at sige til, at han ønskede at skåne hende for at komme ud i flere lignende slagsmål. Det er i hvert tilfælde forståeligt, omend ikke helt undskyldeligt.

I et kort brev fra Hoxie skrevet 7. juni, 1914, beklager han ligesom sin kone meget, at de gik skævt af hinanden, da Brandes var i USA: "I fear that the letters we sent have failed to reach you, and our ships have passed in the night". Han havde gjort sig store anstrengelser for at fă deres breve med invitation til at besøge dem i Washington bragt om bord på Hamburg-Amerika linjens skib "Vaterland”, så Brandes kunne have dem, inden han gik i land, men af uforklarlige grunde nåede de aldrig frem. Hans sidste brev i korrespondancen fra 17. februar, 1915 er skrevet efter Vinnie Reams død og indeholder også hendes sidste uafsendte brev (“a Voice from the Dead"). Hoxie skriver fra et vinterkursted i South Carolina, hvor han er rejst ned for "if possible to find relief from the great sorrow of my life." Med sig havde han hendes efterladte breve og papirer og finder heri til sin overraskelse "mss of her own unpublished essays and poems, which I had never seen ... they tell me of my wasted opportunities." De fortæller måske ikke mindst om hendes spildte muligheder, for det digt han kopierer til Brandes bekræfter endnu engang, at tekstmediet kun var et nødmedium. Hendes skabertrang havde imidlertid været så stærk i de år, hvor vejen til leret var spærret, at hun havde mattet tage til takke med det forhåndenværende medium, nemlig ordet. Når Hoxie kopierer et af hendes digte $\mathrm{i}$ brevet, er det måske i det lønlige håb, at Brandes vil finde det udgivelsesværdigt:

"Too late"

Come back! Come back, ye vanished hours!

I did not know you then.

I did not pluck your blossoming flowers -

Can ye not come again!

The flying hours but speeded by,

With darkness in their train.

"Ye did not know us when we came.

We cannot come again." 
Digtene blev - af indlysende grunde - aldrig trykt, selv om hendes mand skrev: "I will publish some of her poems. Of their literary merit I am not a competent judge, but they reach the heart." Tekstmediet var tydeligt ikke hendes. Når hun skal give udtryk for følelsesmæssig intensitet, transponerer hun teksten op i et højere toneleje med overforbrug af klicheer og arkaismer, dertil kommer, at den sentimentalitet, som Brandes allerede bemærkede i hendes kunst i Rom, nu tager overhånd, og hun kan ikke finde udtryk for de tydeligtvis ægte følelser, der ligger bag.

Kunstneren Vinnie Reams skæbne fortæller os to historier, både historien om "the American girl” og historien om "the American matron". Den sidste kan læses ud af de breve, hun - og især hendes mand - skrev til Brandes, og som findes i Det kongelige Bibliotek. Den første er fortalt af Brandes. Sjældent er "the American girl" blevet afspejlet så fint og smukt i et europæisk spejl, som Vinnie Ream blev det i Brandes' portræt af hende. Begge historier er fortalt i mange varianter i Henry James's værk, hvor især Daisy Miller er kommet til at stå som prototypen på den både stærke og sårbare amerikanske pige, men Brandes' virkelighed overgår James's fiktion. Modsat Vinnie Ream, så døde Daisy Miller indirekte af europæiske fordomme og vanetænkning, mens Vinnie derimod med sin stærke kunstneriske vilje overlevede Europa, hvor så mangen en amerikansk kunstner i det 19. århundrede måtte se sin kunst visne, sådan som tilfældet var for Henry James's Roderick Hudson i romanen af samme navn. Vinnie Reams kunst blomstrede i Rom, til gengæld visnede den i USA.

Vinnie Ream ligger begravet på Arlington militærkirkegården, hvor hendes mand lod opstille en bronzekopi af hendes Sappho statue på graven. Den smukkeste gravskrift over hende står imidlertid ikke på stenen, den blev skrevet mange år tidligere af Brandes over "en Aand, der er i Slægt med min."

Her

hviler

Vinnie Ream

Billedhuggerinde fra Washington

U.S.A.

Sex og tyve Aar gammel

Dette Minde bevares hende af En, der kjendte hende

i sytten Dage

og aldrig glemmer hende. 
Når andet ikke er oplyst, er alle Brandes citater taget fra trykte udgaver af breve til familie og venner samt fra Levned. Barndom og forste Ungdom. Kbh. 1905.

Alle citater fra Henry James's novelle Daisy Miller er fra The Complete Tales of Henry James, ed. Leon Edel, vol. 4, 1876-1882. London. 1962.

Asmundsson, Doris R.: Georg Brandes, Aristocratic Radical. N.Y. 1981.

Baker, Paul R.: The Fortunate Pilgrims: Americans in Italy. Cambr., Mass. 1964.

Eakin, Paul John: The New England Girl. Athens, Ga. 1976.

Fowles, Virginia C.: Henry James's American Girl. Madison. 1984,

Healy, George P.A.: Reminiscences of a Portrait Painter. N.Y. 1894. Repr. 1970.
Rubinstein, Charlotte Streifer: American Women Sculptors: a History of Women Working in Three Dimensions. Bost. 1990.

Rubinstein, Charlotte Streifer: American Women Artists from Early Indian Times to the Present. Bost. 1982

Sherwood, Dolly: Harriet Hosmer. American Sculptor 1830-1908. Columbia and London. 1991.

Story, William Wetmore: Conversations in a Studio. Bost. 1899.

James, Edward T. (ed.): Notable American Women 1607-1950. A Biographical Dictionary. Cambr., Mass. 1973.

Petteys, Chris (ed.): Dictionary of Women Artists, an International Dictionary of Women Artists Born before 1900. Bost. 1985.

Willard, Frances E. and Mary A. Livermore (eds.): $A$ Woman of the Century. 1893. 